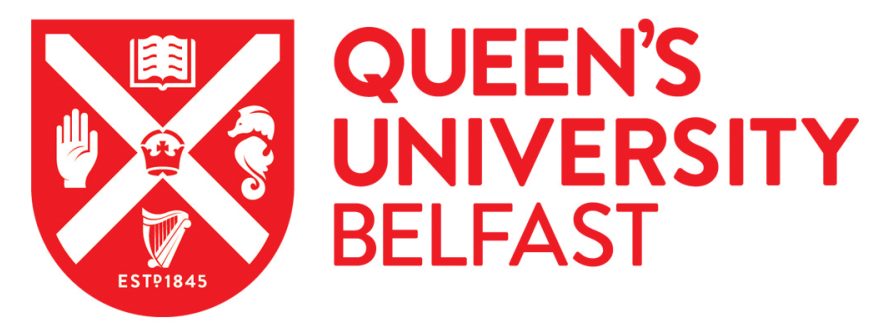

\title{
A multiple streams analysis of the decisions to fund gender-neutral HPV vaccination in Canada
}

\author{
Shapiro, G. K., Guichon, J., Prue, G., Perez, S., \& Rosberger, Z. (2017). A multiple streams analysis of the \\ decisions to fund gender-neutral HPV vaccination in Canada. Preventive Medicine, 100, 123-131.
}

\author{
Published in: \\ Preventive Medicine
}

\section{Document Version:}

Peer reviewed version

Queen's University Belfast - Research Portal:

Link to publication record in Queen's University Belfast Research Portal

\section{Publisher rights}

(C) Elsevier Inc. This manuscript version is made available under the CC-BY-NC-ND 4.0 license http://creativecommons.org/licenses/by-ncnd/4.0/,which permits distribution and reproduction for non-commercial purposes, provided the author and source are cited.

\section{General rights}

Copyright for the publications made accessible via the Queen's University Belfast Research Portal is retained by the author(s) and / or other copyright owners and it is a condition of accessing these publications that users recognise and abide by the legal requirements associated with these rights.

Take down policy

The Research Portal is Queen's institutional repository that provides access to Queen's research output. Every effort has been made to ensure that content in the Research Portal does not infringe any person's rights, or applicable UK laws. If you discover content in the Research Portal that you believe breaches copyright or violates any law, please contact openaccess@qub.ac.uk. 


\section{Accepted Manuscript}

A Multiple Streams analysis of the decisions to fund genderneutral HPV vaccination in Canada

Gilla K. Shapiro, Juliet Guichon, Gillian Prue, Samara Perez, Zeev Rosberger

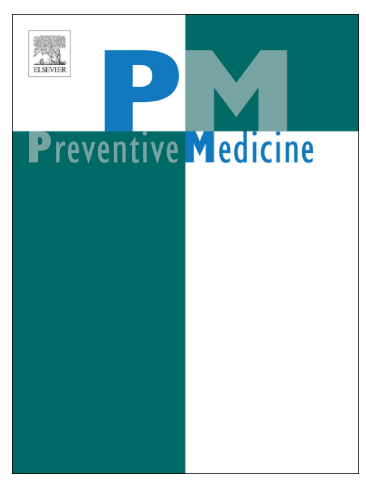

PII:

S0091-7435(17)30137-8

DOI: doi: 10.1016/j.ypmed.2017.04.016

Reference: YPMED 4994

To appear in:

Preventive Medicine

Received date:

5 December 2016

Revised date:

3 April 2017

Accepted date:

9 April 2017

Please cite this article as: Gilla K. Shapiro, Juliet Guichon, Gillian Prue, Samara Perez, Zeev Rosberger, A Multiple Streams analysis of the decisions to fund gender-neutral HPV vaccination in Canada. The address for the corresponding author was captured as affiliation for all authors. Please check if appropriate. Ypmed(2017), doi: 10.1016/ j.ypmed.2017.04.016

This is a PDF file of an unedited manuscript that has been accepted for publication. As a service to our customers we are providing this early version of the manuscript. The manuscript will undergo copyediting, typesetting, and review of the resulting proof before it is published in its final form. Please note that during the production process errors may be discovered which could affect the content, and all legal disclaimers that apply to the journal pertain. 


\section{A Multiple Streams analysis of the decisions to fund gender-neutral HPV vaccination in Canada}

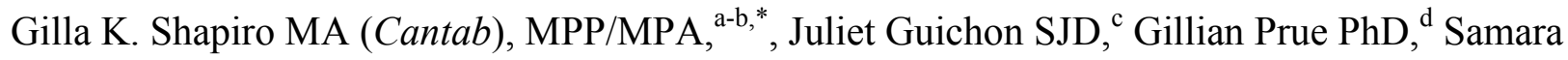
Perez PhD, ${ }^{\mathrm{a}-\mathrm{b}}$ Zeev Rosberger PhD. ${ }^{\mathrm{a}-\mathrm{b}, \mathrm{e}-\mathrm{f}}$

${ }^{a}$ Department of Psychology, McGill University, 1205 Dr. Penfield Avenue, Montreal, Quebec, H3A 1B1

${ }^{\mathrm{b}}$ Lady Davis Institute for Medical Research, Jewish General Hospital, 4333 Côte St-Catherine Road, Montreal, Quebec, H3T 1E4

${ }^{c}$ Department of Community Health Sciences, 3280 Hospital Drive, Calgary, Alberta, Canada, $\mathrm{T} 2 \mathrm{~N} 4 \mathrm{~N} 1$

${ }^{\mathrm{d}}$ School of Nursing and Midwifery, Medical Biology Centre, Queen's University Belfast, 97 Lisburn Road, Belfast, BT9 7BL, Northern Ireland, United Kingdom

${ }^{\mathrm{e}}$ Louise Granofsky Psychosocial Oncology Program, Jewish General Hospital, 4333 Côte StCatherine Road, Montreal, Quebec, H3T 1E4

${ }^{\mathrm{f}}$ Departments of Psychiatry and Oncology, McGill University, 1205 Dr. Penfield Avenue, Montreal, Quebec, H3A 1B1.

* Corresponding author: Gilla K. Shapiro, Department of Psychology, McGill University, 1205 Dr. Penfield Avenue, Montreal, Quebec, H3A 1B1; telephone: +1-514-340-8222, ext. 3978; Email: gilla.shapiro@mail.mcgill.ca

Funding: This work was funded by the Canadian Cancer Society Research Institute (CCSRI; Grant\# 704036). GS was supported by the CIHR Vanier Canada Graduate Scholarship and Queen Elizabeth II Diamond Jubilee Scholarship programs.

Conflict of Interest: Zeev Rosberger reports personal fees from Merck as a consultant on two occasions (November and April, 2015) unrelated to the submitted work. The remaining authors declare no conflict of interest.

Word Count: Abstract 198 words; Manuscript 5,344. 


\begin{abstract}
In Canada, the human papillomavirus (HPV) vaccine is licensed and recommended for females and males. Although all Canadian jurisdictions fund school-based HPV vaccine programs for girls, only six jurisdictions fund school-based HPV vaccination for boys. The research aimed to analyze the factors that underpin government decisions to fund HPV vaccine for boys using a theoretical policy model, Kingdon's Multiple Streams framework. This approach assesses policy development by examining three concurrent, but independent, streams that guide analysis: Problem Stream, Policy Stream, and Politics Stream. Analysis from the Problem Stream highlights that males are affected by HPV-related diseases and are involved in transmitting HPV infection to their sexual partners. Policy Stream analysis makes clear that while the inclusion of males in HPV vaccine programs is suitable, equitable, and acceptable; there is debate regarding cost-effectiveness. Politics Stream analysis identifies the perspectives of six different stakeholder groups and highlights the contribution of government officials at the provincial and territorial level. Kingdon's Multiple Streams framework helps clarify the opportunities and barriers for HPV vaccine policy change. This analysis identified that the interpretation of costeffectiveness models and advocacy of stakeholders such as citizen-advocates and HPV-affected politicians have been particularly important in galvanizing policy change.
\end{abstract}

\title{
Keywords
}

Canada, cancer prevention, health policy, human papillomavirus, men's health, Kingdon Multiple Streams framework, policy analysis, vaccination, vaccine policy 


\section{Introduction}

Most Human Papillomavirus (HPV) infections are asymptomatic and regress in 6-18 months but persistent infection can cause cancer and anogenital warts and can result in morbidity and mortality in females and males (Forman et al. 2012; Giuliano et al. 2014). The prevention of HPV has therefore become a prominent public health priority. Three vaccines, the bivalent (Cervarix ${ }^{\circledR}$, GlaxoSmithKline; protecting against HPV 16/18), quadrivalent (Gardasil ${ }^{\circledR}$, Merck; protecting against HPV 6/11/16/18), and nonavalent (Gardasil ${ }^{\circledR} 9$, Merck; protecting against HPV 6/11/16/18/31/33/45/52/58) have been developed to protect against HPV infections and are approved for use (Public Health Agency of Canada 2016; Centers for Disease Control and Prevention 2010). In Canada, the quadrivalent and nonavalent vaccines have been licensed for females and males (aged 9-26); the bivalent vaccine is licensed only for females (aged 9-45). Health Canada recommends that people receive the vaccines as school-aged children in order to provide the highest level of immunogenicity and to protect them before they become sexually active (Public Health Agency of Canada 2012). As of March 2017, all Canadian provinces and territories fund HPV school-based programs for girls, and six provinces have funded HPV vaccination for boys (Shapiro, Perez, and Rosberger 2016) and three have announced that they will commence funding in September 2017 (CBC News 2017; Government of British Columbia, 2017; Government of New Brunswick, 2017).

As other jurisdictions decide whether to adopt the policy of funding HPV vaccine for boys, it is important to draw upon an understanding of the foundations of this policy change (Eggertson 2012; Stanley 2014). A small but growing literature investigates decision-making processes in health policy and systems in low, middle and high-income countries (Greathouse et al. 2005; Koon et al. 2013). In a systematic review of national decision-making concerning adopting new vaccines, Burchett and colleagues write, "There is a need for more research exploring decisionmaking processes for vaccine adoption, particularly considering how decisions are made, rather than merely who was involved" (Burchett et al. 2012, ii70). To attempt to meet that need, this paper analyzes the underlying factors that have led to decisions to fund HPV vaccination for boys in Canada using a theoretical model of policy change. We use Kingdon's Multiple Streams (MS) framework to explore the policy decisions to fund HPV vaccination for boys because this 
theory offers a broad and multifaceted approach to conceptualize the issues that encourage decision-making and policy change (Kingdon 2011).

\section{Methodology}

In 2008, Walt and colleagues commented on the absence of theoretical frameworks in health policy analysis. The authors argued that, "explicit attention to theory development could benefit public policy practice by deepening our understanding of causality and by bringing coherence to a fragmented body of knowledge"; they highlighted the utility of Kingdon's MS framework among others (Walt et al. 2008, 311). Kingdon's MS framework addresses how certain policies emerge on the public agenda and are considered by decision-makers while others languish (Thurber 2011). Kingdon's MS framework has been applied to investigate diverse issues in health policy development (Cairney 2007; Greathouse et al. 2005). It describes policy development as occurring because of three concurrent, but independent, streams. The Problem Stream analyzes whether an issue has been identified as a problem that is amenable to human control (i.e. in this case, by examining whether HPV and its associated diseases constitute a health problem). The Policy Stream describes the suitability of the proposed solutions for a problem (i.e. by examining whether HPV vaccination of males is an appropriate policy solution in Canadian jurisdictions). Thirdly, the Politics Stream describes the political context whereby policy is determined (i.e. by examining the perspective of important stakeholders). When these three streams come together at critical junctures - a problem is recognized, a solution is developed, and political impetus arises — then a 'policy window' opens, thus creating opportunity for policy development (Kingdon 2011).

\section{Results}

(1) Problem stream: Identifying HPV as a problem for males

HPV has been identified as a health problem in males. HPV is the most common Sexually Transmitted Infection (STI) among males and females (Anic and Giuliano 2011). HPV prevalence in men has been reported to be consistently higher than in females due to the poorer 
natural immune response men have to HPV infection compared to females (Giuliano et al. 2011). Individuals can be unaware that they have contracted HPV because HPV infection is often asymptomatic (Anic and Giuliano 2011). The human papillomavirus becomes a health problem when it causes different sequela such as genital warts and cancer.

Epidemiologists have described a growing burden of HPV-associated cancers in men and have warned about the increasing incidence of anal, penile, rectal and oropharyngeal cancers (Palefsky 2010; Stanley 2012; Alemany et al. 2016). Early research suggests that HPV is associated also with sinonasal, conjunctiva, and lacrimal sac cancer (Zhao, Guo, and Zhang 2016; Knör et al. 2015; Afrogheh et al. 2016 ). HPV-related diseases, including precancerous lesions that require treatment and genital warts, significantly impair psychosocial wellbeing and health-related quality of life (Dominiak-Felden et al. 2013). Moreover, the HPV-related cancer burden in males falls more heavily on an already disadvantaged group; MSM are more susceptible to HPVassociated diseases (Zou et al. 2014; Latini et al. 2014; Glick et al. 2014; Egan v. Canada 1995).

HPV infection in sexually active heterosexual men is problematic also because males can transmit HPV to their female partners. HPV in women is responsible for cervical cancer and can cause vulvar, vaginal, anal, rectal, and oropharyngeal cancers (Palefsky 2010; Public Health Agency of Canada 2016). An association between HPV treatments has also been reported with miscarriage and preterm birth (Maria et al. 2015; Yang et al. 2013; Bonde et al. 2014), though further research is required. HPV infection has been associated with a higher risk of HIV acquisition (Houlihan et al. 2012). HPV infection can be transmitted by a pregnant woman to her foetus, resulting rarely in recurrent respiratory papillomatosis (Palefsky 2010).

The conditions caused by HPV in men, women and infants are largely preventable (Crosignani et al. 2013). However, no early detection measures are currently available to males (e.g. screening or HPV DNA testing) and not all males are included in a government funded prevention strategy (e.g. vaccination).

(2) Policy stream: Identifying HPV vaccination of males as an appropriate policy solution for Canada 
To investigate whether HPV vaccination is an appropriate policy solution, we examine the suitability, equity, acceptability, and cost-effectiveness of this solution in Canada.

Suitability. The safety of the HPV vaccines has been determined in multiple randomized controlled trials and epidemiological reviews (Ferris et al. 2014; Palefsky et al. 2011; Vichin et al. 2015). Adverse events are rare. Most reported reactions concern pain at the injection site, which typically resolves in less than five days (Shearer 2011; Ferris et al. 2014). Extremely rare adverse events include flu-like symptoms (e.g. fever) and anaphylaxis (Brotherton, Zuber, and Bloem 2016).

The HPV vaccine has been shown also to be efficacious. In well-controlled trials, HPV vaccination prevented persistent infections (Ferris et al. 2014), and the HPV vaccine has been found to confer cross-protection against other HPV strains in females (Tabrizi et al. 2014; Wheeler et al. 2012). Recent studies have shown that the proportion of high-grade cervical intraepithelial neoplasia lesions caused by HPV 16 and 18 have declined only among women who received the HPV vaccine (Crosignani et al. 2013; Hariri et al. 2015).

Even though there are fewer studies of the vaccines' preventative effect in males (because the vaccine was initially approved only for females), all indications are that the vaccines demonstrate comparable immunogenicity for both sexes (Hillman et al. 2012; Stillo et al. 2015). The emerging literature on HPV vaccines in males has demonstrated the safety and non-inferior immunogenicity in males (Castellsague et al. 2015; Iversen et al. 2016; Lehtinen et al. 2016; Van Damme et al. 2015; Van Damme et al. 2016; Yang and Bracken, 2016). Pinto et al. (2016) found that vaccinating males induces HPV antibodies in the oral cavity in the majority of males, though it is still unclear whether antibody levels will provide long-term protection against infection. We may not see a direct reduction in cancer incidence in males for a number of years because cancer is a disease of latency; however, all available evidence anticipates a decline of HPV-associated cancers in males in the future because of HPV vaccination (Ferris et al. 2014). 
Because of its safety and efficacy profile, the HPV vaccine has been licensed by Health Canada since 2006 for females and since 2010 for males (Public Health Agency of Canada 2012). HPV vaccination for boys is a feasible solution because boys can easily be vaccinated against HPV within existing school-based vaccination programs in Canada (Canadian Immunization Committee 2014). Moreover, the implementation of a gender-neutral HPV vaccination program will likely be less confusing to the public (Zimet and Rosenthal 2010; Stanley 2012).

Equitability. Funding HPV vaccination for males will increase equity. The argument for vaccinating only girls and protecting boys by the resulting herd immunity, assumes that males are exclusively heterosexual. MSM do not benefit from this policy and are at higher risk of HPV infection (Zou et al. 2014; Latini et al. 2014; Glick et al. 2014). Targeting MSM is cost effective, particularly if MSM receive the HPV vaccine at an early age (Kim 2010; Lin et al. 2017). The United Kingdom addressed this inequity in 2015 by recommending the vaccine for men who identify as gay or bisexual up to age 45 in genitourinary medicine and HIV clinics (Department of Health and Public Health England 2014). Similarly, since September 2015, the province of British Columbia provides the HPV vaccine to male youth who are in custody and care institutions or who identify as MSM (Brotherton, Zuber, and Bloem 2016), though it will offer the vaccine to all boys commencing in September 2017 (Government of British Columbia, 2017). British Columbia's selective approach had practical and ethical problems previously identified (Shapiro, Perez, and Rosberger 2016; Shapiro et al. 2015), including that it unfairly requires school-aged males to self-identify as homosexual to receive a health benefit. The province of Quebec has adopted an inclusive approach by funding the HPV vaccine both for MSM (under age 26) and all boys (in Grade 4) (Gouvernement du Québec 2016).

Some researchers argue that a female only HPV vaccination policy disadvantages not only MSM, but all males who must rely on herd immunity for protection (Stanley 2012).

Problematically, even though girls in Canada may receive the vaccine at no cost, they are not doing so at levels that adequately confer herd immunity. For example, though uptake varies by jurisdiction (e.g. 52.6\% in Nunavut to $89.3 \%$ in Newfoundland and Labrador), only $72.3 \%$ of 12 14 year old girls in Canada received even one dose of the HPV vaccine in 2013 (Gilbert et al. 2016). Moreover, even if herd immunity were achieved in Canada, it would not protect 
Canadian males who have sexual relationships with partners who are, or have come from, outside Canada. A policy that requires males to rely on females for protection from HPV is not equitable. Moreover, such a policy also treats women unequally by placing the burden to protect men on women (Crosignani et al. 2013).

Acceptability. Canadian studies report high acceptability of HPV vaccination for males. For example, a questionnaire conducted in a mid-size Ontario city revealed that mothers supported HPV vaccination for their daughters or sons $(77.8 \%$ and $70.7 \%$ respectively) in their early teens; however, mothers were less willing to consent to vaccination of their younger children, 9 or 10year-old daughters or sons (41.5\% and 38.3\%) (Lenehan et al. 2008). Ogilvie et al. (2008) examined acceptability of HPV vaccination for boys $(\mathrm{N}=1381)$ across Canada and found that $67.8 \%$ of Canadian parents planned to vaccinate their sons but acceptability varied (from $61.7 \%$ in British Columbia/Yukon to $79.8 \%$ in Atlantic Canada) (Ogilvie et al. 2008).

In studies examining uptake after 2012 when the HPV vaccine was recommended for males in Canada, the results have been mixed. McClure et al. (2015) found uptake was high (i.e. 79\%) in P.E.I. after the public program was instituted (McClure et al. 2015). By contrast, Perez et al. (2016) surveyed a national sample of Canadian parents at two time points $(\mathrm{N}=3117, \mathrm{~N}=1427)$, when only P.E.I. and Alberta funded male vaccination. These researchers found less than $3 \%$ of parents reported that their 9-16 year-old sons received the HPV vaccine. Importantly, the vast majority of parents were in the early stages of vaccination adoption suggesting that many parents did not know that HPV vaccination is recommended for boys (Perez et al. 2016).

A number of barriers to acceptability by parents have been identified in the literature and include not receiving a recommendation from a health professional (Newman et al. 2013), lack of knowledge regarding the availability and recommendation of the HPV vaccine (Lenehan et al. 2008), negative attitudes towards vaccination (Ogilvie et al. 2008), as well as cost and logistical issues (Newman et al. 2013). Adolescents may also object to the vaccine due to generic vaccination concerns such as fear of needles (Hilton et al. 2013), or believing there is no need for HPV vaccination because they are not sexually active (Forster et al. 2012). Some Canadians may perceive that if the government has not funded a vaccine then it is unnecessary (Scheifele et 
al. 2014).

Cost-Effectiveness. "Cost-effectiveness" is a term used to justify both funding and not funding HPV vaccination for males. The Alberta Ministry of Health stated that vaccinating boys is costeffective: "Expanding the HPV program to males can save lives, reduce disease and reduce future health care costs in Alberta... The cost savings from this preventative effort could represent cost-savings to the health care system of over \$13.4 million” (Alberta Health 2014). Similarly, the Deputy Chief Public Health officer of P.E.I., Dr. Lamont Sweet, reportedly said, "The new program won't cost more than the original [girls only] vaccination program" (CBC News 2013). By contrast, other provinces justify not funding HPV vaccine for boys claiming that such funding is not cost-effective ( CTV Montreal 2014; Eggertson 2012). Many provinces have not made their cost-effectiveness analyses available publicly, which prevents them from being evaluated and compared.

Most studies modeling cost-effectiveness have reported that vaccinating boys is less costeffective than increasing HPV uptake in females, particularly when there is moderate to high coverage in females (Brisson, Van de Velde, and Boily 2009; Brisson et al. 2011; Chesson et al. 2011; Jit et al. 2008; Pearson et al. 2014; Seto et al. 2012). By contrast, some studies have found male HPV vaccination to be cost-effective, particularly with lower estimated vaccine cost and greater estimated efficacy (Brisson et al. 2016; Burger et al. 2014; Elbasha and Dasbach 2010; Elbasha et al. 2007; Graham et al. 2015; Haeussler et al. 2015). There is substantial heterogeneity in the methodology and model parameters of different cost-effectiveness analyses (Pink et al., 2017). The main drivers of cost-effectiveness of gender-neutral vaccination has been the assumed vaccine and administration costs, whether cost reductions related to all HPVrelated diseases were considered, whether female coverage was sub-optimal, whether herd immunity effects from girls were considered, and wider socio-economic considerations (Burger et al., 2014; Crosignani et al. 2013; Olsen and Jorgensen 2015; Jiang et al. 2013; Kim et al., 2007; Kotsopoulos et al. 2015; Pearson et al., 2014). Almost all models do not take into account sexual relationships with individuals from other jurisdictions, where HPV vaccination uptake rates in females vary widely, from non-existent to high coverage. Sexual relations with 
unvaccinated people from other jurisdictions is a particularly important consideration in Canada given high rates of international travel and immigration.

Modification to vaccine type (e.g. quadrivalent or nonavalent), dosing schedules, and cost of the HPV vaccine can strongly influence cost-effectiveness estimations. Moreover, the World Health Organization (WHO) and the National Advisory Committee on Immunization (NACI) recommended decreasing the HPV vaccine dose from three to two doses (for individuals 9-14 years of age). Some evidence indicates that fewer number of doses (i.e. two or even one) may be sufficient (Sankaranarayanan et al. 2015; WHO 2014). Future cost-effectiveness analyses of male HPV vaccination should also examine recent vaccination rates across Canada, natural immunity (Elbasha and Dasbach 2010), herd immunity (Pearson et al. 2014), errors in vaccine administration (Hibbs et al., 2015), nonavalent vaccination (i.e. 9 HPV types and their associated disease) (Durham et al. 2016; Laprise et al. 2016; Largeron et al. 2017), changes to screening programs (Brisson et al. 2016), two dose schedule (Laprise et al. 2014), sexual behaviour and partnership duration (including early sexual initiation, sexual relationships with partners from other jurisdictions, paying for sex, and the MSM population) (Kim 2010; Van de Velde et al. 2012), possible waning vaccine protection (Jit et al. 2008; Laprise et al. 2014), marginal administration costs (Durham et al. 2016), the burden of non-cervical diseases (e.g. including anus, rectum, and oral/oralpharyngeal cancers as well as anogenital warts) (Burger et al. 2014; Chesson et al. 2011; Laprise et al. 2014), and HPV-related infant prematurity as a result of treatment for Cervical Intraepithelial Neoplasia (Ryser et al. 2015; Soergel et al. 2012; Olsen and Jorgensen 2015; Isidean et al. 2015). While some of these factors have been examined by some authors, we know of no study that has modeled and assessed all these factors simultaneously. Like Pink and colleagues, we advocate that studies report their assumptions and the impact of simplifying assumptions (Pink et al., 2017). Further, an updated systematic review that compares and contrasts these cost-effectiveness analyses is also merited.

(3) Politics Stream: Identifying the perspective of important stakeholders 
The Politics Stream analyzes the political context and the perspectives and partisan influence of stakeholders in the decision arenas (Nowlin 2011). Interest groups can promote or block a policy change (Kingdon 2011). Groups that have a stake in the political debate about HPV vaccination for boys in Canada include the federal and provincial governments, the scientific and medical community, civil society, the media, pharmaceutical companies and school boards.

Government. Canadian provinces and territories are responsible for providing health care to people in Canada (The Constitution Act 1867). Nevertheless, the federal government plays an important role in setting agendas, providing funding, and approving drugs for market. In 2007, the federal government allocated $\$ 300$ million over three years to fund the HPV vaccine for girls (Steben 2008). The current federal government has not announced whether it will fund HPV vaccination for boys (Eggertson 2012). Individual elected representatives have advocated for HPV vaccine funding for boys, such as federal opposition Member of Parliament Peter Kent (Thornhill, Ontario), and Member of the Legislative Assembly of Nova Scotia, Gordon Gosse, both personally affected by HPV-related cancer (Payton 2014).

The Public Health Agency of Canada supports two committees that recommend vaccine use in Canada, namely NACI and the Canadian Immunization Committee (CIC). NACI - an advisory committee of scientific experts - first recommended HPV vaccination for females in 2007 and expanded its recommendation to include males (aged 9 to 26) in 2012 (Public Health Agency of Canada 2016). The CIC - an advisory committee of federal, provincial and territorial health authorities- is mandated to consider vaccine cost, alignment of vaccine programs, and acceptability (Canadian Immunization Committee 2014). In 2007, the CIC highlighted the goal of the HPV vaccination program as reducing the incidence of cervical pre-cancer and cancer (Canadian Immunization Committee 2007); in 2014, the CIC broadened the objective to include reducing other HPV-related diseases and recognized the impact of HPV on males (Canadian Immunization Committee 2014). NACI recommends male vaccination and the CIC favours funding HPV vaccination for boys where it is feasible, cost-effective, and acceptable.

Scientific and Medical Community. The scientific and medical community overwhelmingly agree that HPV vaccination is safe and effective, and that preventing HPV-related disease in 
males is desirable, bar a minority of objections (Leon 2008; Harper and Demars 2014; Lippman et al. 2007). The Canadian Medical Association supports public funding for vaccinating males (Sagan 2014). The Canadian Pharmacists Association writes that "the lack of access to HPV vaccination programs for young men in Canada is needlessly putting the health of Canadians at risk" (Canadian Pharmacists Association 2015). The Federation of Medical Women of Canada has argued that vaccinating boys makes sense when there is a low uptake among girls (Eggertson 2012). The Canadian Paediatric Society has also recommended male HPV vaccination (Moore 2015). Recently, the Society of Obstetricians and Gynaecologists of Canada (SOGC), Society of Canadian Colposcopists, the Society of Gynecologic Oncology of Canada, and the College of Family Physicians of Canada, published a joint statement on the safety of HPV vaccination (SOGC et al. 2015). They explained that HPV is related to cancers that affect females and males, though the statement emphasized female vaccination (SOGC et al. 2015).

Civil society. Many Canadian organizations favour HPV vaccine and male vaccination. For example, the Canadian Cancer Society called the HPV vaccine "a game changer" (Canadian Cancer Society 2013, 10). Immunize Canada, a consortium of professional organizations guided by the Canadian Public Health Association, and a citizens' group, HPV Canada, have supported HPV vaccination for males (HPV Canada 2015). When, in February 2015, the HPV vaccine was disparaged in a Canadian newspaper with the largest circulation, the Toronto Star, doctors, public health experts and researchers formed a coalition that became the Canadian Alliance to Support Immunization (CASI). Their denunciation of the misleading article helped lead to its retraction (Guichon and Kaul 2015; Chantal 2015). However, some anti-vaccination groups in Canada, such as Vaccine Choice Canada, continue to oppose HPV vaccine for both sexes.

Media. Sensational articles about HPV have been published in the Canadian media including Macleans' cover story "Our girls are not guinea pigs", and the aforementioned Toronto Star's "A wonder drug's dark side", and Le Devoir's "Urgent call for a moratorium on HPV vaccination in Quebec" (Gulli, George, and Intini 2007; Bruser and Mclean 2015; Rail, Molino, and Lippman 2015). Reading negative reports has been found to influence parents to refuse to vaccinate their children (Nan and Madden 2012; Gollust et al. 2010). 
A 2009 content analysis of Canadian and U.S. national news coverage of HPV found that, in Canada, $28 \%$ of articles about the HPV vaccine were negative, whereas $43 \%$ were neutral and 29\% were positive (Abdelmutti and Hoffman-Goetz 2009). A 2016 Canadian content analysis, conducted after NACI's recommendation to vaccinate boys, found that the proportion of newspaper articles in Canada that mentioned HPV vaccination for boys significantly increased between 2012 and 2014; nevertheless, only half of all those articles discussed HPV vaccination for boys (Perez et al. 2016).

Social media is another forum where HPV vaccination concerns can be voiced and circulated to Canadian audiences quickly. Sites such as Twitter quickly disseminate misinformation regarding HPV (Dunn et al. 2015). Some research has evaluated online comments to news articles (Feinberg et al. 2015), blogs or online discussion forums (Penta and Baban 2014, Keelan et al. 2010, Nan and Madden 2012), YouTube videos (Ache and Wallace 2008, Briones et al. 2012), and Twitter (Mahoney et al. 2015, Bahk et al. 2016, Dunn et al. 2015, Zhou et al. 2015, Surian et al. 2016). The balance of positive and negative content and type of concerns expressed appears to vary by social media platform and requires further investigation and surveillance.

Pharmaceutical Companies. Pharmaceutical companies, GlaxoSmithKline and Merck, are also stakeholders that directly influence the policy debate by setting the vaccine price in each province. They also lobby for their vaccines to be licensed, recommended, marketed, and publicly funded in Canada. In 2008, Gardasil received the Prix Galien Canada Innovative Product Award, which recognized its contribution to patient care in Canada (Prix Galien Canada 2008). The commercial promotion of vaccines is limited in Canada by law; advertisements must follow strict federal content regulations (Food and Drugs Act 1985; Scheifele et al. 2014); nevertheless, pharmaceutical companies invest in marketing their products and Canadians are often exposed to HPV vaccination through other countries' advertisements (e.g. in magazines and internationally read newspapers). The pharmaceutical industry works also with scientists by funding research, including HPV vaccination trials. Although academic participation in drugrelated science is important for innovation, understandable concern arises about relationships between researchers and industry (Lewis et al. 2001). Pharmaceutical companies also give funds to medical societies. For example, Merck provided the SOGC with an unrestricted grant (\$1.5 
million) to educate Canadians about HPV; the SOGC reported using peer-reviewed work to do so (Page 2007).

School boards. Because school aged children are typically vaccinated in school in Canada (Guichon et al. 2013), school boards are a notable stakeholder in this debate. Soon after provinces announced HPV vaccination program for girls, some Roman Catholic bishops publicly discouraged HPV vaccination, encouraging "a proper education in chastity" (Wingle 2007) and abstinence (Smith et al. 2008). Twelve school districts in Alberta, Ontario and the Northwest Territories banned the vaccine from being administered in publicly funded schools (Guichon et al. 2013). The HPV vaccine ban negatively affected HPV vaccination uptake because girls whose easy access was blocked by Catholic school boards were less likely to receive the vaccine than other girls. HPV vaccine bans caused particular hardship to girls with a lower socioeconomic status (Musto et al. 2013). Because of advocacy which created pressure for the school trustees (Cotter 2014), and the publication of Bednarcyk et al.'s (2012) research disproving the notion that administration of HPV vaccine is associated with sexual activity (Bednarczyk et al. 2012), all school boards reversed their bans by May 2014 (HPV Canada 2015; Guichon et al. 2013). Nevertheless, this issue remains salient; in September 2014 the Calgary Catholic School District continued to include the Alberta episcopal letter that discourages HPV vaccination in the health information package for parents (Blackwell 2014). No new publicly-funded Catholic school board barriers have been reported regarding boys and HPV vaccination.

A study by McClure et al. (2015) in P.E.I. found that students (girls and boys) in the English Language School Board were more than twice as likely as students in the French Language School Board to receive all three doses of the HPV vaccine (McClure et al. 2015). Although the authors postulated that this finding is probably related to socio-demographic differences, more research is needed to examine the reasons that different linguistic school boards have varying HPV vaccine uptake (McClure et al. 2015).

\section{Discussion}


To date, few countries have publicly-funded HPV vaccination programs for boys: Australia (since 2013), Austria (since 2014), Barbados (since 2013), Canada (six jurisdictions; since 2013, with an additional three regions announcing programs to commence September 2017), Israel (since 2015), New Zealand (since 2017), Italy (since 2017), Liechtenstein (since 2016), Switzerland (i.e. The Republic and Canton of Geneva, since 2016), and the United States (Brotherton, Zuber, and Bloem 2016; Cancer Council Victoria 2016; ECDC 2016; Efrati 2015; Favato 2017; Freyer 2016; HPV Information Centre 2016; Shapiro et al. 2016; New Zealand Ministry of Health 2017). Because Canada is an international leader in funding HPV vaccination for boys, analyzing what led to policy development in Canada may inform health care policy and practice on a national and international level. This paper used Kingdon's MS framework to examine diverse factors that were (or were not) involved in incorporating boys into HPV vaccination programs in Canada. Kingdon's MS framework theorizes that all three streams must be open for policy change to occur (i.e. a problem is recognized, a solution is developed, and political impetus arises (Kingdon 2011). Accordingly, any one factor-such as insufficient research, public demand, or a strongly opposed stakeholder - can derail policy change.

Analysis from the Problem Stream identified that HPV causes HPV-associated cancers and anogenital warts in men, that males can transmit HPV to their sexual partners and that offspring can be negatively affected. The incidence of HPV-associated cancers has been increasing in Canada and worldwide. To build on the available evidence, future research should evaluate and monitor the cross-protection, possible type replacement, safety and efficacy of the HPV vaccines in males.

Analysis from the Policy Stream identified that vaccinating boys is a suitable and equitable solution that has precedent in the universal female HPV vaccination program. While acceptability of HPV vaccination among boys in some provinces (e.g. P.E.I) appears strong, greater research is required to understand why provincial uptake varies. The most contentious factor has been cost-effectiveness analyses, which have varied depending on models and methodologies. Crucial to cost-effectiveness analyses is the vaccine price that provinces and territories negotiate with pharmaceutical companies, which is not public knowledge and inclusion of additional costs. Lowering vaccine costs through price negotiations and reducing 
delivery costs (by administering more than one vaccine at the same time) is a current priority to reach cost-effectiveness for male HPV vaccination (Baussano et al. 2014). Indeed, Australia has obtained a lower vaccine price for males compared to females (Brotherton, Zuber, and Bloem 2016). Moreover, the availability of funds also appears to have been crucial for policy change in some provinces. For example, P.E.I. appears to have had existing funds in the Department of Health and Wellness budget and a relatively small population of boys to be vaccinated. In Alberta, the Alberta Cancer Prevention Legacy Fund likely helped address the cost barrier (Alberta Health Services 2016). Moving to a two or one-dose regime also makes the HPV vaccination program more affordable; this change likely affected Nova Scotia's decision to include boys, which coincided with the decision to offer only two doses to girls and boys (Fraser 2015). Cost-effectiveness, though an important factor, should not be the only consideration for initiating a vaccine program. Future research could expand on this evaluation of the policy stream by incorporating related criteria considered in the advisory process of immunization recommendations (e.g. adequateness of vaccine supply) (Nijsten et al. 2016).

The Politics Stream identified relevant stakeholders and their positions. The scientific and medical communities favour funding male vaccination, and have recently advocated for male vaccination publicly. The federal and provincial/territorial agencies favour funding male vaccination, though some provinces have emphasized the importance that the vaccine be costeffective for males. Pharmaceutical companies have strongly promoted male vaccination. Generally speaking, the Canadian media and civil society have positively assessed the HPV vaccine; however, male HPV vaccination has been less visible in the media compared to female vaccination, some notable news articles have caused a stir, and anti-vaccine groups are active in this debate. Lastly, a number of Catholic school districts opposed HPV vaccination in the past, banning or discouraging female vaccination. The momentum required to overturn the Catholic school vaccine bans (predominantly in Alberta where local, national and international media coverage favoured in-school HPV vaccination) may have created a 'window of opportunity' for HPV vaccination in boys.

Although Kingdon's MS framework offers a broad and multifaceted approach, it is not exhaustive. It would be useful for future research to evaluate other (high and low income) 
countries and conduct international comparisons, which necessitates taking into account the potential role of policy diffusion (Shipan and Volden, 2012). It would also be helpful to extend this research by considering other policy frameworks that examine decision-making (Koon et al., 2013; Walt et al. 2008). For example, there is a burgeoning field examining how health policy systems research could be more directly embedded into the decision-making sphere (Koon et al., 2013). The WHO and collaboration among National Immunization Technical Advisory Groups on immunization (NITAGs) are well positioned to lead improvements in the use of evidence in policy decision-making and make informed immunization decisions for their local contexts (Adjagba et al., 2015; Perronne et al., 2016). Because there is little overlap in the decisionmaking processes of NITAGs (Nijsten et al., 2016; Ricciardi et al., 2015), future research could inform the development of an international standard for an evidence-based process of decisionmaking for immunization policy. Such research should advance the conceptual decision-making framework for policy analysis.

\section{Conclusion}

As of March 2017, nine Canadian provinces offered, or intend soon to offer, publicly funded school-based HPV vaccination for males and females, albeit with slight variations. This paper's analysis identified that the interpretation of cost-effectiveness models, herd immunity calculations, and advocacy by stakeholders (including citizen-advocates and HPV-affected politicians) have been particularly important in galvanizing policy change. There are multiple, simultaneously ongoing policy debates regarding HPV vaccination in Canada and other developed countries on matters such as: how many doses children should receive, at what age children should receive the vaccine, which vaccine should be administered, and whether the HPV vaccine should be funded for high-risk boys only. Because Kingdon's MS framework helps focus and analyze such public health decisions, it may be useful in future policy research on the implementation of HPV vaccination programs for boys in Canada and internationally. 


\section{Acknowledgments}

The authors thank Antonia Maoini and Daniel Weinstock for their helpful comments on an earlier version of this article. 


\section{References}

Abdelmutti, N., and L. Hoffman-Goetz. 2009. "Risk messages about HPV, cervical cancer, and the HPV vaccine Gardasil: a content analysis of Canadian and U.S. national newspaper articles." Women Health 49 (5):422-40. doi: 10.1080/03630240903238776.

Ache, K.A., and L.A. Wallace. 2008. "Human Papillomavirus vaccination coverage on YouTube." Am J Prev Med 35(4):389-92.

Adjagba, A., K. Senouci, R. Biellik, N. Batmunkh, P. C. Faye, A. Durupt, B. D. Gessner, and A. da Silva. 2015. "Supporting countries in establishing and strengthening NITAGs: lessons learned from 5 years of the SIVAC initiative”. Vaccine 29;33(5):588-95.

Afrogheh, A. H., F. A. Jakobiec, R. Hammon, H. E. Grossniklaus, J. Rocco, N. I. Lindeman, P. M. Sadow, and W. C. Faquin. 2016 "Evaluation for High-risk HPV in Squamous Cell Carcinomas and Precursor Lesions Arising in the Conjunctiva and Lacrimal Sac." Am J Surg Pathol 40 (4):519-28. doi: 10.1097/PAS.0000000000000581.

Alberta Health. 2014 "Human Papillomavirus vaccine." http://www.health.alberta.ca/newsroom/imm-HPV.html Alberta Health Services. 2016. "About Ablerta Prevents Cancer." http://albertapreventscancer.ca/about/ Accessed September 30, 2016.

Alemany, L., A. Cubilla, G. Halec, E. Kasamatsu, B. Quiros, E. Masferrer, et al. 2016. "Role of Human Papillomavirus in Penile Carcinomas Worldwide." European Urology. doi: doi:10.1016/j.eururo.2015.12.007.

Anic, G. M., and A. R. Giuliano. 2011. "Genital HPV infection and related lesions in men." Prev Med 53 Suppl 1:S36-41. doi: 10.1016/j.ypmed.2011.08.002.

Bahk CY, Cumming M, Paushter L, Madoff LC, Thomson A, Brownstein JS. 2016. "Publicly Available Online Tool Facilitates Real-Time Monitoring Of Vaccine Conversations And Sentiments". Health affairs 35(2):341-347.

Braganza, C. 2015. "The Toronto Star's Gardasil controversy: A timeline." Toronto Star, February 12. http://www.j-source.ca/article/toronto-stars-gardasil-controversy-timeline. Accessed September 30, 2016. 
Baussano, I., J. Dillner, F. Lazzarato, G. Ronco, and S. Franceschi. 2014. "Upscaling human papillomavirus vaccination in high-income countries: impact assessment based on transmission model." Infectious agents and cancer 9 (4).

Bednarczyk, R. A., R. Davis, K. Ault, W. Orenstein, and S. B. Omer. 2012. "Sexual activityrelated outcomes after human papillomavirus vaccination of 11- to 12-year-olds." Pediatrics 130 (5):798-805. doi: 10.1542/peds.2012-1516.

Blackwell, T. 2014. "Debate over HPV vaccine flares up in Alberta after Catholic leaders warn shots encourage pre-marital sex." National Post, September 21. http://news.nationalpost.com/2014/09/21/debate-over-hpv-vaccine-flares-up-in-albertaafter-catholic-leaders-warn-shots-encourage-pre-marital-sex/. Accessed September 30, 2016.

Bonde, U. , J. S. Joergensen, O. Mogensen, and R. F. Lamont. 2014. "The potential role of HPV vaccination in the prevention of infectious complications of pregnancy." Expert Rev Vaccines 13 (11):1307-16. doi: 10.1586/14760584.2014.944164.

Briones R, Nan X, Madden K, and Waks L. 2012. "When vaccines go viral: an analysis of HPV vaccine coverage on YouTube." Health Commun 27:478-485.

Brisson, M., N. Van de Velde, and M. C. Boily. 2009. "Economic evaluation of human papillomavirus vaccination in developed countries." Public Health Genomics 12 (56):343-51. doi: 10.1159/000214924.

Brisson, M., N. van de Velde, E. L. Franco, M. Drolet, and M. C. Boily. 2011. "Incremental impact of adding boys to current human papillomavirus vaccination programs: role of herd immunity." J Infect Dis 204 (3):372-6. doi: 10.1093/infdis/jir285.

Brisson, M., J. Laprise, H.W. Chesson, M. Drolet, T. Malagon, M. oily, and L.E. Markowitz. 2016. "Health and Economic Impact of Switching From a 4-Valent to a 9-Valent HPV Vaccination Program in the United States" J Natl Cancer Inst 108 (1): djv282.

Brotherton, J. M. L., F. Zuber, and P. J. N. Bloem. 2016. "Primary Prevention of HPV through Vaccination: Update on Current Global Status." Curr Obst Gynecol Reports 5:210-224. doi: 10.1007/s13669-016-0165-Z.

Bruser, D., and J. Mclean. 2015. "HPV Vaccine Gardasil has a dark side, Star investigation finds." Toronto Star, February 6. http://web.archive.org/web/20150205215614/http://www.thestar.com/news/canada/2015/0 
2/05/hpv-vaccine-gardasil-has-a-dark-side-star-investigation-finds.html. Accessed September 30, 2016.

Burger, E.A., S. Sy, M. Nygard, I.S. Kristiansen, and J.J. Kim. 2014. Prevention of HPV-Related Cancers in Norway: Cost-Effectiveness of Expanding the HPV Vaccination Program to Include Pre-Adolescent Boys. PLOS ONE 9(3):e89974.

Burchett, H. E., S. Mounier-Jack, U. K. Griffiths, and A. J. Mills. 2012. "National decisionmaking on adopting new vaccines: a systematic review." Health Policy Plan 27 Suppl 2:ii62-76. doi: 10.1093/heapol/czr049.

Cairney, P. 2007. "A 'Multiple Lenses' Approach to Policy Change: The Case of Tobacco Policy in the UK." British Politics 2 (1):45-68.

Canadian Cancer Society. 2013. "An Ounce of Prevention." Believe, http://www.cancer.ca/ /media/cancer.ca/AB/about\%20us/BelieveMagazine_2013_Spring_ AB.pdf. Accessed September 30, 2016.

Canadian Immunization Committee (CIC)-Public Health Agency of Canada. 2007.

Recommendations on a human papillomavirus immunization program. http://www.phacaspc.gc.ca/publicat/2008/papillomavirus-papillome/papillomavirus-papillome-12eng.php\#111. Accessed September 30, 2016.

Canadian Immunization Committee (CIC)- Public Health Agency of Canada. 2014.

"Recommendations for human papillomavirus immunization programs." Canada Communicable Disease Report 40 (8).

http://publications.gc.ca/collections/collection_2014/aspc-phac/HP40-107-2014-eng.pdf . Accessed September 30, 2016.

Canadian Pharmacists Association. 2015. CPhA Calls for HPV Strategy for Young Men to Save Lives. Ottawa. https://www.pharmacists.ca/news-events/news/cpha-calls-for-hpv-strategyfor-young-men-to-save-lives/. Accessed September 30, 2016.

Cancer Council Victoria. 2016. HPV Vaccine: Why was the HPV vaccine program introduced? http://www.hpvvaccine.org.au/the-hpv-vaccine/why-was-the-program-introduced.aspx. Accessed September 30, 2016.

Castellsagué, X., A.R. Giuliano, S. Goldstone, A. Guevara, O. Mogensen, J.M. Palefsky, T. Group, C. Shields, K. Liu, R. Maansson, A. Luxembourg, and S.S. Kaplan. 2015. 
"Immunogenicity and safety of the 9-valent HPV vaccine in men." Vaccine 33(48):6892901.

CBC News. 2013. "P.E.I. boys offered HPV vaccine". http://www.cbc.ca/news/canada/princeedward-island/p-e-i-boys-offered-hpv-vaccine-1.1339059 Apr 19, Accessed September 30, 2016

CBC News. 2017. "Sask. expands HPV vaccine program to include boys". http://www.cbc.ca/news/canada/saskatoon/saskatchewan-budget-hpv-vaccine-boys1.4037922 Mar 23, Accessed April 2, 2017.

Centers for Disease Control and Prevention. 2010 "FDA Licensure of Quadrivalent Human Papillomavirus Vaccine (HPV4, Gardasil) for Use in Males and Guidance from the Advisory Committee on Immunization Practices (ACIP)." Centers for Disease Control and Prevention http://www.cdc.gov/mmwr/preview/mmwrhtml/mm5920a5.htm. Accessed September 30, 2016.

Chesson, H. W., D. U. Ekwueme, M. Saraiya, E. F. Dunne, and L. E. Markowitz. 2011. "The cost-effectiveness of male HPV vaccination in the United States." Vaccine 29 (46):844350. doi: 10.1016/j.vaccine.2011.07.096.

Cotter, John. 2014. "HPV Canada: last of 12 school boards to allow vaccine." Macleans, May 27. http://www.macleans.ca/news/hpv-canada-last-of-12-school-boards-to-allow-vaccine/. Accessed September 30, 2016.

CTV Montreal. 2014. "The HPV Vaccine, free for boys too?" http://montreal.ctvnews.ca/thehpv-vaccine-free-for-boys-too-1.1639708\#ixzz3SW0iH3Mb January 14, Accessed September 30, 2016.

Crosignani, P., A. De Stefani, G. M. Fara, A. M. Isidori, A. Lenzi, C. A. Liverani, A. Lombardi, F. S. Mennini, G. Palu, S. Pecorelli, A. P. Peracino, C. Signorelli, and G. V. Zuccotti. 2013. "Towards the eradication of HPV infection through universal specific vaccination." BMC Public Health 13:642. doi: 10.1186/1471-2458-13-642.

Department of Health and Public Health England. 2014 "JCVI interim position statement on HPV vaccination of men who have sex with men (MSM)." https://www.gov.uk/government/publications/interim-statement-on-hpv-vaccination-ofmen-who-have-sex-with-men. Accessed September 30, 2016. 
Dominiak-Felden, G., C. Cohet, S. Atrux-Tallau, H. Gilet, A. Tristram, and A. Fiander. 2013. "Impact of human papillomavirus-related genital diseases on quality of life and psychosocial wellbeing: results of an observational, health-related quality of life study in the UK." BMC Public Health 13:1065.

Dunn, A. G., J. Leask, X. Zhou, K. D. Mandl, and E. Coiera. 2015. "Associations Between Exposure to and Expression of Negative Opinions About Human Papillomavirus Vaccines on Social Media: An Observational Study." J Med Internet Res 17 (6):e144. doi: 10.2196/jmir.4343.

Durham, D.P., M.L. Ndeffo-Mbah, L.A. Skrip, F.K. Jones, C.T. Bauch, \& A.P. Galvani. 2016. "National- and state-level impact and cost-effectiveness of nonavalent HPV vaccination in the United States." Proc Natl Acad Sci USA 113(18):5107-12.

Egan v. Canada. 1995. 2 SCR 513.

Eggertson, L. 2012. "Provinces weighing HPV vaccination of boys." Canadian Medical Association Journal 184 (5):E250-1. doi: 10.1503/cmaj.109-4140.

Elbasha E.H., and E.J. Dasbach. 2010. "Impact of vaccinating boys and men against HPV in the United States". Vaccine 28:6858-67.

Elbasha, E.H., E.J. Dasbach, and R.P. Insinga. 2007. "Model for assessing human papillomavirus vaccination strategies". Emerg Infect Dis 13(1):28-41.

European Centre for Disease Prevention and Control (ECDC). 2012. "Introduction of HPV vaccines in European Union Countries - An Update." http://ecdc.europa.eu/en/publications/Publications/20120905_GUI_HPV_vaccine_update.p df. Accessed September 30, 2016.

European Centre for Disease Preention and Control (ECDC). 2016 "Recommended immunisations for human papillomavirus infection." http://vaccineschedule.ecdc.europa.eu/pages/scheduler.aspx Accessed September 30, 2016.

Favato, G. 2016. “Gender (in)equality in Human Papilloma Virus (HPV) vaccinations and treatment. In: Gender Summit 9 (GS9) : Gender-based research, innovation and development for sustainable economies and societal wellbeing"; 08 - 09 Nov 2016, Brussels, Belgium. (Unpublished). http://eprints.kingston.ac.uk/36322/1/Favato-G36322.pdf. Accessed March 11, 2017. 
Feinberg, Y., J. A. Pereira, S. Quach, J. C. Kwong, N. S. Crowcroft, S. E. Wilson, M. Guay, Y. Lei, and S. L. Deeks. 2015. "Understanding Public Perceptions of the HPV Vaccination Based on Online Comments to Canadian News Articles." PLoS One 10 (6):e0129587. doi: 10.1371/journal.pone.0129587.

Ferris, D., R. Samakoses, S. L. Block, E. Lazcano-Ponce, J. A. Restrepo, K. S. Reisinger, J. Mehlsen, A. Chatterjee, O. E. Iversen, H. L. Sings, Q. Shou, T. A. Sausser, and A. Saah. 2014. "Long-term study of a quadrivalent human papillomavirus vaccine." Pediatrics 134 (3):e657-65. doi: 10.1542/peds.2013-4144.

Food and Drugs Act. 1985. R.S.C., c. F-27, s. 9(1).

Forman, D., C. de Martel, C. J. Lacey, I. Soerjomataram, J. Lortet-Tieulent, L. Bruni, J. Vignat, J. Ferlay, F. Bray, M. Plummer, and S. Franceschi. 2012. "Global burden of human papillomavirus and related diseases." Vaccine 30 Suppl 5:F12-23. doi: 10.1016/j.vaccine.2012.07.055.

Forster, A. S. , L. A. Marlow, J. Wardle, J. Stephenson, and J. Waller. 2012. "Interest in having HPV vaccination among adolescent boys in England." Vaccine 30:4505-4510.

Fraser L. April 9, 2015. "Nova Scotia health budget includes meningitis, boys' HPV vaccinations." Herald News, http://thechronicleherald.ca/novascotia/1279611-nova-scotiahealth-budget-includes-meningitis-boys'-hpv-vaccinations. Accessed September 30, 2016.

Freyer, F. J. 2016. "How did R.I. win acceptance of HPV vaccine?" Boston Globe, August 26. https://www.bostonglobe.com/metro/2016/08/25/how-did-win-acceptance-hpvvaccine/7gujQkn522RoNT4DnOq6mN/story.html. Accessed September 30, 2016.

Garland, S. M. 2014. "The Australian Experience With the Human Papillomavirus Vaccine." Clinical Therapeutics 36 (1):17-23. doi: http://dx.doi.org/10.1016/j.clinthera.2013.12.005.

Gilbert, N. L., H. Gilmour, E. Dubé, S. E. Wilson, and J. Laroche. 2016. "Estimates and determinants of HPV non-vaccination and vaccine refusal in girls 12 to 14 years of age in Canada: Results from the Childhood National Immunization Coverage Survey, 2013." Human Vaccines \& Immunotherapeutics 12 (6):1484-1490. doi: 10.1080/21645515.2016.1153207.

Giuliano, A. R., A. G. Nyitray, A. R. Kreimer, C. M. Pierce Campbell, M. T. Goodman, S. L. Sudenga, J. Monsonego, and S. Franceschi. 2014. "EUROGIN 2014 roadmap: Differences in human papillomavirus infection natural history, transmission and human 
papillomavirus-related cancer incidence by gender and anatomic site of infection."

International Journal of Cancer. doi: 10.1002/ijc.29082.

Giuliano, AR. , JM. Palefsky, S. Goldstone, and et al. 2011. "Efficacy of quadrivalent HPV

Vaccine against HPV infection and disease in males." N Engl J Med 364:401-411.

Glick, S. N., Q. Feng, V. Popov, L. A. Koutsky, and M. R. Golden. 2014. "High rates of incident and prevalent anal human papillomavirus infection among young men who have sex with men." J Infect Dis 209 (3):369-76. doi: 10.1093/infdis/jit441.

Gollust, S. E., A. F. Dempsey, P. M. Lantz, P. A. Ubel, and E. F. Fowler. 2010. "Controversy undermines support for state mandates on the human papillomavirus vaccine." Health Aff 29 (11):2041-6. doi: 10.1377/hlthaff.2010.0174.

Gouvernement du Québec. 2016. Human papillomavirus (HPV) Vaccination Program. http://sante.gouv.qc.ca/en/programmes-et-mesures-daide/programme-de-vaccinationcontre-les-infections-par-les-virus-du-papillome-humain-vph/\#admissibilite. Accessed September 30, 2016.

Government of British Columbia. 2016. B.C. extends free HPV coverage to boys. https://news.gov.bc.ca/releases/2017HLTH0003-000027. Accessed February 24, 2017.

Government of New Brunswick. 2017. Listening and Getting Things Done, Budget 2017-2018. http://www2.gnb.ca/content/dam/gnb/Departments/fin/pdf/Budget/20172018/BudgetSpeech2017-2018.pdf. Accessed March 13, 2017.

Government of Ontario. 2016. Ontario's HPV Immunization Program. edited by Ministry of Health and Long-Term Care. Ontario. Government of Ontario. 2016. http://www.health.gov.on.ca/en/ms/hpv/. Accessed September 30, 2016.

Graham, D. M., W. Isaranuwatchai, S. Habbous, C. de Oliveira, G. Liu, L. L. Siu, and J. S. Hoch. 2015. "A cost-effectiveness analysis of human papillomavirus vaccination of boys for the prevention of oropharyngeal cancer." Cancer:1785-1792. doi: 10.1002/cncr.29111.

Gravel P. "VPH: vacciner ou non?" Le Devoir, November 7, 2015. http://www.ledevoir.com/societe/science-et-technologie/454635/sante-vph-vacciner-ounon. Accessed September 30, 2016.

Greathouse, L. W., E. J. Hahn, C. T. Okoli, T. A. Warnick, and C. A. Riker. 2005. "Passing a smoke-free law in a pro-tobacco culture: a multiple streams approach." Policy Polit Nurs Pract 6 (3):211-20. doi: 10.1177/1527154405278775. 
Guichon, J., and R. Kaul. 2015. "Science shows HPV vaccine has no dark side." Toronto Star, February 11. https://www.thestar.com/opinion/commentary/2015/02/11/science-showshpv-vaccine-has-no-dark-side.html. Accessed March 8, 2017.

Guichon, J. R., I. Mitchell, P. Buffler, and A. Caplan. 2013. "Citizen intervention in a religious ban on in-school HPV vaccine administration in Calgary, Canada." Preventive medicine 57 (5):409-413. doi: 10.1016/j.ypmed.2013.06.005.

Gulli, Cathy, Lianne George, and John Intini. 2007. "Our girls are not guinea pigs (cover story)." Maclean's 120 (33):38-42.

Haeussler, K., A. Marcellusi, F.S. Mennini, G. Favato, M. Picardo, G. Garganese, M. Bononi, S. Costa, G. Scambia, P. Zweifel, A. Capone, and G. Baio. 2015. Cost-Effectiveness Analysis of Universal Human Papillomavirus Vaccination Using a Dynamic Bayesian Methodology: The BEST II Study. Value in Health 18(8): 956-968.

Hariri, S., N. M. Bennett, L. M. MNiccolai, S. Schafer, I. U. Park, K. C. Bloch, E. R. Unger, E. Whitney, and et al. 2015. "Reduction in HPV 16/18-associated high grade cervical lesions following HPV vaccine introduction in the United States - 2008-2012." Vaccine 33:16081613.

Harper, D. M., and L. R. Demars. 2014. "Primary strategies for HPV infection and cervical cancer prevention." Clin Obstet Gynecol 57 (2):256-78. doi: 10.1097/grf.0000000000000027.

Hibbs, B.F., P.L. Moro, P. Lewis, E.R. Miller, T.T. Shimabukuro. 2015. "Vaccination errors reported to the Vaccine Adverse Events Reporting System, (VAERS) United States, 20002013. Vaccine 33(28):3171-8.

Hillman, R. J., A. R. Giuliano, J. M. Palefsky, S. Goldstone, E. D. Moreira, Jr., E. Vardas, C. Aranda, H. Jessen, D. G. Ferris, F. Coutlee, J. B. Marshall, S. Vuocolo, R. M. Haupt, D. Guris, and E. I. Garner. 2012. "Immunogenicity of the quadrivalent human papillomavirus (type 6/11/16/18) vaccine in males 16 to 26 years old." Clinical and Vaccine Immunology 19 (2):261-7. doi: 10.1128/cvi.05208-11.

Hilton, S., C. Patterson, E. Smith, H. Bedford, and K. Hunt. 2013. "Teenagers' understandings of and attitudes towards vaccines and vaccine-preventable diseases: a qualitative study." Vaccine 31:2543-2550. 
Houlihan, C. F., N. L. Larke, D. Watson-Jones, K. K. Smith-McCune, S. Shiboski, P. E. Gravitt, J. S. Smith, L. Kuhn, C. Wang, and R. Hayes. 2012. "Human papillomavirus infection and increased risk of HIV acquisition. A systematic review and meta-analysis." AIDS 26 (17):2211-22. doi: 10.1097/QAD.0b013e328358d908.

HPV Canada. 2015. http://www.hugyourkids.org/. Accessed September 30, 2016.

HPV Information Centre. 2016 "Summary Reports." http://www.hpvcentre.net/summaryreport.php. Accessed September 30, 2016.

Efrati, I. 2015. "Not Just for Girls: Israeli Boys to Receive HPV Vaccinations Too." Haaretz, http://www.haaretz.com/israel-news/science/.premium-1.646171. Accessed September 30, 2016.

Isidean, S. D., J. E. Tota, J. A. Gagnon, and E. L. Franco. 2015. "Human papillomavirus vaccines: key factors in planning cost-effective vaccination programs." Expert Rev Vaccines 14 (1):119-33. doi: 10.1586/14760584.2015.964213.

Iversen, O.E., M.J. Miranda, A. Ulied, T. Soerdal, E. Lazarus, K. Chokephaibulkit, S.L. Block, A. Skrivanek, A.G. Nur Azurah, S.M. Fong, V. Dvorak, K.H. Kim, R.M. Cestero, M. Berkovitch, M. Ceyhan, M.C. Ellison, M.A. Ritter, S.S Yuan, M.J. DiNubile, A.J. Saah, and A. Luxembourg. 2016. "Immunogenicity of the 9-Valent HPV Vaccine Using 2-Dose Regimens in Girls and Boys vs a 3-Dose Regimen in Women.” JAMA 316(22): 24112421. doi: 10.1001/jama.2016.17615.

Jiang, Y., A. Gauthier, M. J. Postma, L. Ribassin-Majed, N. Largeron, and X. Bresse. 2013. "A critical review of cost-effectiveness analyses of vaccinating males against human papillomavirus." Hum Vaccin Immunother 9 (11):2285-95.

Jit, M., Y.H. Choi, and W.J. Edmunds. 2008. "Economic evaluation of human papillomavirus vaccination in the United Kingdom”. BMJ 337:a769.

Kasting, M., G. K. Shapiro, Z. Rosberger, J. Kahn, and G. D. Zimet. 2016. "Tempest in a teapot: A systematic review of HPV vaccination and risk compensation research." Human Vaccines and Immunotherapeutics 12 (6):1435-1450.

Keelan, J., V. Pavri, R. Balakrishnan, and K. Wilson. 2010. "An analysis of the Human Papilloma Virus vaccine debate on MySpace blogs." Vaccine 28(6):1535-40. doi: 10.1016/j.vaccine.2009.11.060. 
Kim, J. J. 2010. "A cost-effectiveness analysis of targeted HPV vaccination of men who have sex with men in the United States." Lancet Infect Dis. 10 (12):845-852.

Kim, J.J., B. Andres-Beck, and S.J. Goldie. 2007. The value of including boys in an HPV vaccination programme: A cost-effectiveness analysis in a low-resource setting. British Journal of Cancer 97:1322-1328.

Kingdon, J.W. 2011. Agendas, Alternatives, and Public Policies: Longman.

Knör, M., K. Tziridis, A. Agaimy, J. Zenk, and O. Wendler. 2015. "Human Papillomavirus (HPV) Prevalence in Nasal and Antrochoanal Polyps and Association with Clinical Data". PLOS One 10:1-15. doi: 10.1371/journal.pone.0141722.

Koon, A.D., K. D. Rao, N. T. Tran, and A. Ghaffar. 2013 "Embedding health policy and systems research into decision-making processes in low- and middle-income countries." Health Research Policy and Systems 11:30.

Kotsopoulos, N. , M. Connolly, and V. Remy. 2015. "Quantifying the broader economic consequences of quadrivalent human papillomavirus (HPV) vaccination in Germany applying a government perspective framework." Health Economics Review 5 (23). doi: 10.1186/s13561-015-0054-6.

Largeron, N., K.U. Petry, J. Jacob, F. Bianic, D. Anger, \& M. Uhart. 2017. "An estimate of the public health impact and cost-effectiveness of universal vaccination with a 9-valent HPV vaccine in Germany." Expert Rev Pharmacoecon Outcomes Res. 17(1):85-98.

Laprise J.F., M. Drolet, M. Boily, M. Jit, C. Sauvageau, E.L. Franco, P. Lemieux-Mellouki, T. Malagon, and M. Brisson. "Comparing the cost-effectiveness of two-and three-dose schedules of human papillomavirus vaccination: A transmission-dynamic modelling study. Vaccine 32:5845-5853.

Laprise J.F., L.E. Markowitz, H.W. Chesson, M. Drolet, and M. Brisson. 2016. "Comparison of 2-Dose and 3-Dose 9-Valent Human Papillomavirus Vaccine Schedules in the United States: A Cost-effectiveness Analysis". J Infect Dis 214(5):685-688.

Latini, A., M. G. Dona, L. Ronchetti, A. Giglio, D. Moretto, M. Colafigli, V. Laquintana, M. Frasca, M. Zaccarelli, A. Antinori, A. Cristaudo, and M. Giuliani. 2014. "Prevalence of anal human papillomavirus infection and cytologic abnormalities among HIV-infected and HIV-uninfected men who have sex with men." J Int AIDS Soc 17 (4 Suppl 3):19662. doi: 10.7448/ias.17.4.19662. 
Lehtinen, M., T. Eriksson, D. Apter, M. Hokkanen, K. Natunen, J. Paavonen, E. Pukkala, M.G. Angelo, J. Zima, M.P. David, S. Datta, D. Bi, F. Struyf, and G. Dubin. 2016. "Safety of the human papillomavirus (HPV)-16/18 AS04-adjuvanted vaccine in adolescents aged 12-15 years: Interim analysis of a large community-randomized controlled trial.” Hum Vaccin Immunother 12(12):3177-3185. doi: 10.1080/21645515.2016.1183847.

Lemmens, T., and C. Telfer. 2012. "Access to information and the right to health: the human rights case for clinical trials transparency." Am J Law Med 38 (1):63-112.

Lenehan, J. G., K. C. Leonard, S. Nandra, C. R. Isaacs, A. Mathew, and W. A. Fisher. 2008. "Women's knowledge, attitudes, and intentions concerning Human Papillomavirus vaccination: findings of a waiting room survey of obstetrics-gynaecology outpatients." Journal of obstetrics and gynaecology Canada $: J O G C=$ Journal d'obstetrique et gynecologie du Canada : JOGC 30 (6):489-499.

Leon, R. 2008. "Ladies first: should boys be vaccinated against HPV?" Can Fam Physician 54 (7):967-8, 972-3.

Lewis, S., P. Baird, R. G. Evans, W. A. Ghali, C. J. Wright, E. Gibson, and F. Baylis. 2001. "Dancing with the porcupine: rules for governing the university-industry relationship." Canadian Medical Association Journal 165 (6):783-5.

Lexchin, J., N. Arya, and S. Singh. 2010. "Gardasil® - The New HPV Vaccine: The Right Product, the Right Time? A Commentary." Healthcare Policy 5 (4):26-36.

Lin, A., K.J. Ong, P. Hobbelen, E. King, D. Mesher, W.J. Edmunds, P. Sonnenberg, R. Gilson, I. Bains, Y.H. Choi, C. Tanton, K. Soldan, and M. Jit. 2017. Impact and cost-effectiveness of selective human papillomavirus vaccination of men who have sex with men. Clin Infect Dis 64(5):580-588.

Lippman, A., R. Melnychuk, C. Shimmin, and M. Boscoe. 2007. "Human papillomavirus, vaccines and women's health: questions and cautions." Canadian Medical Association Journal 177 (5):484-7. doi: 10.1503/cmaj.070944.

Mahoney, L.M., T. Tang, K. Ji, and J. Ulrich-Schad. 2015. "The Digital Distribution of Public Health News Surrounding the Human Papillomavirus Vaccination: A Longitudinal Infodemiology Study." JMIR Public Health Surveill 1 (39):e2. 
Manitoba Health. 2015. Province expands HPV immunization program to include males. http://news.gov.mb.ca/news/index.html?archive=\&item=36477. Accessed September 30, 2016.

Maria, K., M. Anita, A. Marc, P. Maria, A. Antonios, M. Pierre PL, B. Phillip, and P. Evangelos. 2015. "Fertility and early pregnancy outcomes after conservative treatment for cervical intraepithelial neoplasia." Cochrane Database of Systematic Reviews 9. doi: 10.1002/14651858.CD008478.pub2.

McClure, C. A., M. A. MacSwain, H. Morrison, and C. J. Sanford. 2015. "Human papillomavirus vaccine uptake in boys and girls in a school-based vaccine delivery program in Prince Edward Island, Canada." Vaccine 33:1786-1790. doi: 10.1016/j.vaccine.2015.02.047.

Moore, Dorothy L. 2015. Your Child's Best Shot: A parent's guide to vaccination. Ottawa: Canadian Paediatric Society.

Musto, R., Jodi E. Siever, J. C. Johnston, J. Seidel, M. S. Rose, and D. A. McNeil. 2013. "Social equity in Human Papillomavirus vaccination: a natural experiment in Calgary Canada." BMC Public Health 13 (640).

Nan, X., and K. Madden. 2012. "HPV vaccine information in the blogosphere: how positive and negative blogs influence vaccine-related risk perceptions, attitudes, and behavioral intentions." Health Communication 27:829-836 doi: 10.1080/10410236.2012.661348.

Newman, P. A., C. H. Logie, N. Doukas, and K. Asakura. 2013. "HPV vaccine acceptability among men: a systematic review and meta-analysis." Sex Transm Infect 89 (7):568-74. doi: 10.1136/sextrans-2012-050980.

New Zealand Ministry of Health. Human Papillomavirus (HPV). http://www.health.govt.nz/your-health/healthy-living/immunisation/immunisation-olderchildren/human-papillomavirus-hpv?gclid=CLiHib78zNICFdW1wAoddcMGEg. Accessed March 11, 2017.

Nijsten, D., H. Houweling, A. Durupt, and A. Adjagba. 2016. “Overlapping topics in advisory reports issued by five well-established European National Immunization Technical Advisory Groups from 2011 to 2014.” Vaccine 34:6200-6208.

Nowlin, M. C. 2011. "Theories of the Policy Process: State of the Research and Emerging Trends." Policy Studies Journal 39:41-60. doi: 10.1111/j.1541-0072.2010.00389_4.x. 
Ogilvie, G. S., V. P. Remple, F. Marra, S. A. McNeil, M. Naus, K. Pielak, T. Ehlen, S. Dobson, D. M. Patrick, and D. M. Money. 2008. "Intention of parents to have male children vaccinated with the human papillomavirus vaccine." Sex Transm Infect 84 (4):318-23. doi: 10.1136/sti.2007.029389.

Olsen, J., and T. R. Jorgensen. 2015. "Revisiting the cost-effectiveness of universal HPVvaccination in Denmark accounting for all potentially vaccine preventable HPV-related diseases in males and females." Cost Effectiveness and Resource Allocation 13 (4):1-10. doi: 10.1186/s12962-015-0029-9.

Page, S. 2007. "To Market a Drug." The Vancouver Sun, May 14.

Palefsky, J. M. 2010. "Human papillomavirus-related disease in men: not just a women's issue." J Adolesc Health 46 (4 Suppl):S12-9. doi: 10.1016/j.jadohealth.2010.01.010.

Palefsky, J. M., A. R. Giuliano, S. Goldstone, E. D. Moreira, Jr., C. Aranda, H. Jessen, R. Hillman, D. Ferris, F. Coutlee, M. H. Stoler, J. B. Marshall, D. Radley, S. Vuocolo, R. M. Haupt, D. Guris, and E. I. Garner. 2011. "HPV vaccine against anal HPV infection and anal intraepithelial neoplasia." N Engl J Med 365 (17):1576-85. doi: 10.1056/NEJMoa1010971.

Payton, L. 2014. "Peter Kent wants Joe Oliver to fund HPV vaccine for boys." CBC News, http://www.cbc.ca/news/politics/peter-kent-wants-joe-oliver-to-fund-hpv-vaccine-forboys-1.2792609. Accessed September 30, 2016.

Pearson A.L, G. Kvizhinadze1, N. Wilson, M. Smith, K. Canfell, and T. Blakely. 2014. "Is expanding HPV vaccination programs to include school-aged boys likely to be value-formoney: a cost-utility analysis in a country with an existing school-girl program”. BMC Infectious Diseases 14:351.

Penta, M. A., and A. Baban. 2014. "Dangerous agent or saviour? HPV vaccine representations on online discussion forums in Romania." Int J Behav Med 21(1):20-8.

Perez, S., C. Fedoruk, G. K. Shapiro, and Z. Rosberger. 2016. "Giving boys a shot: The HPV vaccine portrayal in Canadian newspapers." Health Communication 31 (12):1527-1538

Perez, S., O. Tatar, G. K. Shapiro, E. Dubé, G. Ogilvie, J. Guichon, V. Gilca, and Z. Rosberger. 2016. "Psychosocial determinants of parental human papillomavirus (HPV) vaccine decision-making for sons: Methodological challenges and initial results of a pan-Canadian longitudinal study." BMC Public Health. 
Perronne, C., A. Adjagba, P. Duclos, D. Floret, H. Houweling, C. Le Goaster, D. Lévy-Brühl, F. Meyer, K. Senouci, and O. Wichmann. 2016. "Implementing efficient and sustainable collaboration between National Immunization Technical Advisory Groups: Report on the 3rd International Technical Meeting, Paris, France, 8-9 December 2014". Vaccine 34(11):1325-30.

Pink, J., B. Parker, and S. Petrou. 2016. “Cost effectiveness of HPV vaccination: A systematic review of modeling approaches. Pharmaeconomics 34(9):847-61. doi: 10.1007/s40273-016-0407-y.

Pinto, L.A., T.J. Kemp, B.N. Torres, K. Isaacs-Soriano, D. Ingles, M. Abrahamsen, Y. Pan, E. Lazcano-Ponce, J. Salmeron, and A.R. Giuliano. 2016. "Quadrivalent Human Papillomavirus (HPV) Vaccine Induces HPV-Specific Antibodies in the Oral Cavity: Results From the Mid-Adult Male Vaccine Trial”. J Infect Dis 214(8):1276-83. doi: 10.1093/infdis/jiw359.

Prix Galien Canada. 2008. "2008 Innovative Product Award." http://eng.prix-galiencanada.com/2008_laureates.html. Accessed September 30, 2016.

Public Health Agency of Canada. 2012. "Update on Human Papillomavirus (HPV) Vaccines." http://www.phac-aspc.gc.ca/std-mts/hpv-vph/fact-faits-eng.php. Accessed September 30, 2016.

Public Health Agency of Canada. 2016. An Advisory Committee Statement (ACS) National Advisory Committee on Immunization (NACI): Updated Recommendation on Human Papillomavirus (HPV) Vaccines: 9-valent HPV vaccine and clarification of minimum intervals between doses in the HPV immunization schedule. http://www.healthycanadians.gc.ca/publications/healthy-living-vie-saine/humanpapillomavirus-9-valent-vaccine-update-recommendation-mises-a-jour-recommandationspapillome-humain-vaccin-nonavalent/index-eng.php. Accessed September 30, 2016.

Rail, G. , L. Molino, and A. Lippman. 2015. "Appel urgent: un moratoire sur la vaccination contre les VPH." Le Devoir, October 5.

http://www.ledevoir.com/societe/sante/451710/vaccination-contre-les-vph-appel-urgent-aun-moratoire. Accessed September 30, 2016.

Ricciardi, G.W., M. Toumi, C. Weil-Olivier, E.J. Ruitenberg, D. Danko, G. Duru, J. Picazo, Y. Zollner, G. Poland, and M. Drummond. 2015. "Comparison of NITAG policies and 
working processes in selected developed countries". Vaccine 33(1): 3-11.

Ryser, M. D., K. McGoff, D. P. Herzog, D. J. Sivakoff, and E. R. Myers. 2015. "Impact of coverage-dependent marginal costs on optimal HPV vaccination strategies." Epidemics 11:32-47. doi: http://dx.doi.org/10.1016/j.epidem.2015.01.003.

Sagan, A. 2014. "HPV vaccine: Why boys are less likely to get it." $C B C$, http://www.cbc.ca/news/health/hpv-vaccine-why-boys-are-less-likely-to-get-it-1.2756037. Accessed September 30, 2016.

Sankaranarayanan, R., P. R. Prabhu, M. Pawlita, T. Gheit, N. Bhatla, R. Muwonge, and et al. 2015. "Immunogenicity and HPV infection after one, two, and three doses of quadrivalent HPV vaccine in girls in India: a multicentre prospective cohort study." The Lancet Oncology 18 (1):67-77.

Sauvageau, C., B. Duval, V. Gilca, F. Lavoie, and M. Ouakki. 2007. "Human papilloma virus vaccine and cervical cancer screening acceptability among adults in Quebec, Canada." BMC Public Health 7 (1):304. doi: 10.1186/1471-2458-7-304.

Scheifele, D. W., B. J. Ward, S. A. Halperin, S. A. McNeil, N. S. Crowcroft, and G. Bjornson. 2014. "Approved but non-funded vaccines: accessing individual protection." Vaccine 32 (7):766-70. doi: 10.1016/j.vaccine.2013.12.027.

Schuster, M. 2014. "Human papillomavirus vaccines: WHO position paper, October 2014Recommendations." Vaccine. doi: 10.1016/j.vaccine.2014.12.002.

Seto, K., F. Marra, A. Raymakers, and C. A. Marra. 2012. "The cost effectiveness of human papillomavirus vaccines: a systematic review." Drugs 72 (5):715-43. doi: 10.2165/11599470-000000000-00000.

Shapiro, G. , J. Guichon, S. Perez, and Z. Rosberger. 2015 "British Columbia's flawed HPV vaccination policy." http://policyoptions.irpp.org/issues/september-2015/british-columbiasflawed-hpv-vaccination-policy/ Accessed September 30, 2016.

Shapiro, G. K. , S. Perez, and Z. Rosberger. 2016. "Including males in Canadian human papillomavirus vaccination programs: a policy analysis." Canadian Medical Association Journal April. doi: 10.1503/cmaj.150451

Shearer, Brenna D. . 2011. HPV Vaccination: Understanding the Impact on HPV Disease. Purple Paper 34.

Shipan, C. R., and C. Volden. 2012. Policy Diffusion: Seven Lessons for Scholars and 
Practitioners." Public Administration Review 72(6): 788-796.

Smith, R.W., D Motiuk, F Henry, G Pettipas, L Bouchard, and M Chatlain. 2008 "A message to Catholic parents/guardians and the Catholic educational community." http://ccsdmedia.s3.amazonaws.com/wpcontent/uploads/2014/08/Alberta_Bishops_letter.pdf Accessed September 30, 2016.

Soergel, P. , L. Makowski, C. Schippert, I. Staboulidou, U. Hille, and P. Hillemanns. 2012. "The cost efficiency of HPV vaccines is significantly underestimated due to omission of conisation-associated prematurity with neonatal mortality and morbidity." Hum Vaccin Immunother 8 (2):243-51.

Stanley, M. 2012. "Perspective: Vaccinate boys too." Nature 488 (7413):S10. doi: 10.1038/488S10a.

Stanley, M. 2014. "HPV vaccination in boys and men." Hum Vaccin Immunother 10 (7):21092111.

Steben, M, Boucher F, Guichon J, Franco E, and et al. October 8, 2015. " Une prise de position irresponsable! Les risques reli's l'infection par le VPH d'passent largement ceux qui sont associs la vaccination." Le Devoir, http://www.ledevoir.com/societe/sante/451978/lareplique-vaccination-contre-le-vph-une-prise-de-position-irresponsable. Accessed September 30, 2016.

Steben, M. 2008. "Do you approve of spending \$300 million on HPV vaccination?: yes." Can Fam Physician 54 (2):174, 176, 178, 180.

Stillo, M., P. Carrillo Santisteve, and P. L. Lopalco. 2015. "Safety of human papillomavirus vaccines: a review." Expert Opin Drug Saf:1-16. doi: 10.1517/14740338.2015.1013532.

Stupiansky, N. W., A. B. Alexander, and G. D. Zimet. 2012. "Human papillomavirus vaccine and men: what are the obstacles and challenges?" Current Opinion in Infectious Diseases 25 (1):86-91. doi: 10.1097/QCO.0b013e32834ed5be.

Surian, D., N.D. Quoc, K. Georgina, J. Mark, E. Coiera, and A.G. Dunn. 2016. "Characterizing Twitter Discussions About HPV Vaccines Using Topic Modeling and Community Detection." JMIR 18(8):e232.

Tabrizi, S. N., J. M. Brotherton, J. M. Kaldor, S. R. Skinner, B. Liu, D. Bateson, K. McNamee, M. Garefalakis, S. Phillips, E. Cummins, M. Malloy, and S. M. Garland. 2014. "Assessment of herd immunity and cross-protection after a human papillomavirus 
vaccination programme in Australia: a repeat cross-sectional study." Lancet Infect Dis 14 (10):958-66. doi: 10.1016/s1473-3099(14)70841-2.

The Constitution Act. 1867. 30 \& 31 Vict, c 3, s. 92.

The Society of Obstetricians and Gynaecologists of Canada, Society of Canadian Colposcopists,

The Society of Gynecologic Oncology of Canada, and The College of Family Physicians of Canada. 2015. "Joint Position Statement: Safety of Gardasil HPV vaccine." https://sogc.org/wp-content/uploads/2015/02/HPVvaccinePositionStatement_Final.pdf . Accessed September 30, 2016.

Thurber, J.A. 2011. "Introduction". Agendas, Alternatives, and Public Policies: Longman. Torgerson, R., and M. MacAdam. 2007. "HPV Vaccine Funded in Canada." Health Policy Monitor. http://hpm.org/en/Surveys/CPRN _-

_Canada/10/HPV_Vaccine_Funded_in_Canada.html. Accessed September 30, 2016. Van Damme, P., S.E. Olsson, S. Block, X. Castellsague, G.E. Gray, T. Herrera, L.M. Huang, D.S. Kim, P. Pitisuttithum, J. Chen, S. Christiano, R. Maansson, E. Moeller, X. Sun, S. Vuocolo, and A. Luxembourg. 2015. "Immunogenicity and Safety of a 9-Valent HPV Vaccine.” Pediatrics 136(1):e28-39. doi: 10.1542/peds.2014-3745.

Van Damme, P., C.J. Meijer, D. Kieninger, A. Schuyleman, S. Thomas, A. Luxembourg, and M. Baudin. 2016. "A phase III clinical study to compare the immunogenicity and safety of the 9-valent and quadrivalent HPV vaccines in men." Vaccine 34(35):4205-12. doi: 10.1016/j.vaccine.2016.06.056.

Van de Velde, N., M.C. Boily, M. Drolet, E.L. Franco, M.H. Mayrand, E.V. Kliewer, F. Coutlee, J.F. Laprise, T. Malagon, and M. Brisson. 2012. "Population-level impact of the bivalent, quadrivalent, and nonavalent human papillomavirus vaccines: a model-based analysis." $J$ Natl Cancer Inst 104(22):1712-23.

Vichin, M., P. Bonanni, N.P. Klein, S.M. Garland, S.L. Block, S.K. Kjaer, H.L. Sings, G. Perez, R.M. Haupt, A.J. Saah, F. Lievano, C. Velicer, R. Drury, and B.J. Kuter. 2015. An overview of quadrivalent human papillomavirus vaccine safety: 2006 to 2015. Pediatr Infect Dis J 34(9): 983-91.

Walt, G., J. Shiffman, H. Schneider, SF. Murray, R. Brugha, and L. Gilson. 2008. "'Doing' health policy analysis: methodological and conceptual reflections and challenges." Health Policy and Planning 23:308-317. doi: 10.1093/heapol/czn024. 
Wheeler, C. M., X. Castellsague, S. M. Garland, A. Szarewski, J. Paavonen, P. Naud, J. Salmeron, S. N. Chow, D. Apter, H. Kitchener, J. C. Teixeira, S. R. Skinner, U. Jaisamrarn, G. Limson, B. Romanowski, F. Y. Aoki, T. F. Schwarz, W. A. Poppe, F. X. Bosch, D. M. Harper, W. Huh, K. Hardt, T. Zahaf, D. Descamps, F. Struyf, G. Dubin, and M. Lehtinen. 2012. "Cross-protective efficacy of HPV-16/18 AS04-adjuvanted vaccine against cervical infection and precancer caused by non-vaccine oncogenic HPV types: 4year end-of-study analysis of the randomised, double-blind PATRICIA trial." Lancet Oncol 13 (1):100-10. doi: 10.1016/s1470-2045(11)70287-x.

Wingle J. 2007. "A message to Directors of Education of Catholic School Boards and to the Catholic educational community." http://www.dpcdsb.org/NR/rdonlyres/A1D21062D28C-4410-A564-

BAE63779DFAF/128089/Bishops20letter20re20HPV20Vaccine2020acbo.pdf. Accessed September 30, 2016.

World Health Organization. 2014. "Human papillomavirus vaccines: WHO position paper, October 2014." Weekly epidemiological record 43:465-492.

Yang, Y., C. W. Jia, Y. M. Ma, L. Y. Zhou, and S. Y. Wang. 2013. "Correlation between HPV sperm infection and male infertility." Asian J Androl 15 (4):529-32. doi: 10.1038/aja.2013.36.

Yang, D.Y., and K. Bracken. 2016. Update on the new 9-valent vaccine for human papillomavirus prevention. Can Fam Physician 62(5):399-402.

Zhao, R. W. , Z. Q. Guo, and R. X. Zhang. 2016. "Human papillomavirus infection and the malignant transformation of sinonasal inverted papilloma: A meta-analysis." J Clin Virol 79:36-43. doi: 10.1016/j.jcv.2016.04.001.

Zhou, X., E. Coiera, G. Tsafnat, D. Arachi, M. S. Ong, and A.G. Dunn. 2015. "Using social connection information to improve opinion mining: Identifying negative sentiment about HPV vaccines on Twitter." Stud Health Technol Inform 216:761-5.

Zimet, G. D., and S. L. Rosenthal. 2010. "HPV vaccine and males: Issues and challenges." Gynecologic Oncology 117 (2, Supplement):S26-S31. doi: http://dx.doi.org/10.1016/j.ygyno.2010.01.028.

Zou, H., S. N. Tabrizi, A. E. Grulich, Garland. S. M., J. S. Hocking, C. S. Bradshaw, A. Morrow, G. Prestage, A. M. Cornall, C. K. Fairley, and M. Y. Chen. 2014. "Early acquisition of 
anogenital human papillomavirus among teenage men who have sex with men." $J$ Infect Dis 209 (5):642-51. doi: 10.1093/infdis/jit626. 


\section{Highlights}

- Canada is an international leader in funding HPV vaccination for school-aged boys.

- Kingdon's framework helps clarify the landscape that led to male HPV vaccination.

- HPV is problematic for males, their sexual partners, and offspring.

- Male vaccination is suitable, equitable, and acceptable; however, cost-effectiveness is debated.

- Stakeholders including citizen-advocates and HPV-affected politicians were important in galvanizing policy change. 